\title{
The Effect of Using the Scientific Approach Through Concept Understanding and Critical Thinking in Science
}

\author{
S. Syarifuddin \\ SD Inpres 12/79 Cinennung, Desa Cinennung Kec. Palakka, Kab. Bone, Indonesia \\ Email: unding_syarif@yahoo.co.id \\ Received: 16 August 2017; Revised: 19 December 2017; Accepted: 27 December 2017
}

\begin{abstract}
This research aimed to find out: (1) the effect of scientific approach through concept understanding in science, (2) the effect of scientific approach through critical thinking in science, and (3) the effect of scientific approach through concept understanding and critical thinking in science. The research was a quasi experimental research using pretest-posttest control group design. The population of the research was the fifth grade school elementary students in the first cluster of Palakka Bone amounted of 125 students. Technique of collecting sample was cluster random sampling which was 71 students. Data were analyzed with independent sample t-tes dan MANOVA test. The research findings showed: (1) There is a significant positive effect of scientific approach through concept understanding in science, the result obtained 0.003 , (2) There is a significant positive effect of scientific approach through critical thinking in science; the result obtained 0.000 , (3) there is a significant positive effect of scientific approach through concept understanding and critical thinking; the result obtained 0.000 . In conclusion, the scientific approach is effective to use in science class in improving students' concept understanding and critical thinking.
\end{abstract}

Keywords: Scientific approach, understanding concept, critical thinking

How to Cite: Syarifuddin, S. (2018). The effect of using the scientific approach through concept understanding and critical thinking in science. Jurnal Prima Edukasia, 6(1), 21-31. doi:http://dx.doi.org/10.21831/jpe.v6i1.15312

Permalink/DOI: http://dx.doi.org/10.21831/jpe.v6i1.15312

\section{Introduction}

The quality of human resources (HR) in a nation determines the high civilization of the nation. The high of the quality of human resources in a nation will determine the nation's ability to build advanced and superior civilization. In contrast, a nation whose low quality of human resources will also have low ability to build advanced and superior civilization, and as the impact, the civilization of a nation has low quality compared to other nations.

The improving of the quality of human resources becomes very urgent and need to be realized, especially when to face the global competition. The improving of the quality of human resources should be conducted as early and through serious and right steps to reach. For that purpose, education is an important means to improve the human resources to ensure the sustainability of nation-building.

Education is an organized, planned, and long life effort that aimed to guide the students to be good, mature, and cultured. To achieve the guidance of this principle, the principle of education should have oriented to the development of all aspects of the students potency, including of cognitive, affective, and implicate to psychomotor aspects. This is as confirmed in the Republic of Indonesian's Law no.20 year 2003 about National Education System on Chapter 1 verse 1, which defines Education as a conscious and planned effort to create an learning atmosphere and learning process in order the students can actively develop their potence to have spiritual power, self-control, personality, intelligence, noble character, as well as necessary skills for himself, society, nation, and state (Presiden Republik Indonesia, 2003).

The education as a conscious and planned effort is through learning in the school. In this term, learning process that is one of the main activities of the education process must be prepared and planned in order the whole students' competencies can achieve in the learning process. By learning process, students may gain an understanding that leads to changes 
attitudes and behaviors through mastery of knowledge, skills, and values. This process goes with the student experience in daily life and achieves the long-term changes in behavior (Abante, Almendral, Manansala, \& Mañibo, 2014 , p. 18). In the learning process, teachers have a duty and role that is very crucial to determine the success of learning objectives. One of the teachers' duty and role is to create conditions that support the learning process of students, and the learning may goes optimally by manipulating the learning environment in order the students may learn in easy way. On the other hand, students must actively seek the information, solve the problems, propose ideas, and practice which aims the student master new abilities or competencies permanently.

One of the aspects that must be mastered by students as important provision to become superior and advanced human resources in the future is the science and technology. The mastery of science and technology encourage through science learning as early as possible. Generally, science learning aim to create student-centered learning environments based on cognitive and constructivist approaches in order the students are expected to master the critical skills, creative, communicative, scientific research, problem solving, information technology using, and entrepreneurship. By science learning, the students are required to understand the basic concepts of science and technology, and relate to daily life experiences outside the school (Gömleksiz, 2012, p. 116).

The science learning in Indonesia is taught since at the level of basic education through the subjects of Natural Sciences (IPA). Natural Science (IPA) is one of the main subjects in the curriculum of education in Indonesia, including in elementary school (SD). The concept of science in elementary school is an integrated concept, involving the subjects of chemistry, biology, and physics. As mandated in the Curriculum 2013, the science learning should develop to integrative scince with applicative-oriented, developing the students' thinking skills, skills to learn independently, stimulating students' curiosity, and caring and responsible attitudes toward the natural environment.

The science learning is learning based on principles, process which builds the students' scientific attitudes toward the concepts in IPA subject. By the science learning, students are expected to develop their thinking skills, work and have scientific attitude in the process of dealing and solving the problems, especially in the application of science learning in everyday life. Thus may achieve if students are able to understand the concepts in science learning and able to develop the critical thinking skills. By mastery the two things; the ability to understand the concept and the critital thinking skills, students' are expected to become an advanced, superior, and achievement.

Understanding the concept is a level of ability that expected on students is able to understand the meaning or concepts, situations, and facts. Meanwhile the term of concept means as the conclusion of a definition that consists of two or more facts with the same characteristics (Widiawati, Pudjawan, \& Margunayasa, 2015). To make understand the concept in the lesson, teachers need to teach in a real context by relate to the surrounding environment. This may increase the students' understanding to the material in the learning process, and may develop their critical thinking skills.

Critical thinking skills are very essential, and it must develop and master by students. Critical thinking skills are important and essential because the students may make their judgments based on accurate information, able to explain their thoughts, and able to solve the problems. Critical thinking is a well-directed and clear process used in mental activities such as problem solving, decision making, persuading, analyzing assumptions, and conducting scientific research (Kartimi, Liliasari, \& Permanasari, 2012, p. 57). Critical thinking is the implemen-tation of learning behavior related to the problem solving. Generally, students who have critical thinking will use the basic principles and concepts to answer the "how" and "why" questions. In this term, students are required to use certain appropriate cognitive strategies to test the depth of an idea in solving the problems and handle the mistakes or lacks (Sumaryati \& Sumarmo, 2013, p. 30).

The success of learning in achieve the goals is determined by various factors, and one of the factors is the learning approach implemented by the teacher. Based on preliminary observations conducted at SD first cluster of Palakka district, Bone Regency, the learning approach is not yet fully able to facilitate students in the process of understanding the concept and critical thinking skills. Most of the learning still applies the expository learning approach which the learning process is centered 
on the teacher, and it makes the students passive in the learning process. The result is seen in the low score of the average student report cards of the Year 2016/2017 Semester 2 class V SD first cluster of District Palakka, Bone Regency is 70 of the Minimum Criteria of Completeness Criteria (KKM) of 78 which has been established by the school.

The learning approach is mostly focused on such a number of facts or concepts. The focus of the learning process is still limited to the achievement of material completion targets in each semester to meet the demands of the curriculum. The teacher is paid less attention to the issues of real life in the learning process in school. As the result, students are less able to understand the usefulness of the material learned from the school.

Dewi \& Mukminan (2016, p. 21) stated, the learning when declare as successful in assist the students achieving the expected goals are influenced by several factors, one of the factors is the approach used by teachers. The learning approach is a means to make teacher easy in providing the learning services and also make students easy to understand the material delivered by the teacher, by maintaining a well learning atmosphere in order able to achieve the meaningful learning.

One of the learning approaches that may apply in the process of science learning is a scientific learning approach. Through a scientific approach, the process of learning science in elementary school is conducted through various stages of scientific activities such as observing, questioning, do a simple experiments, reasoning, and communicating the results of learning; and learning in the scientific approach is not just an acitivity to deliver of various collections of science concepts that must memorized by students. The activities will make the students have direct experience, and the learning results will be more memorable and meaningful for students.

The Scientific Approach may increase the students' understanding to the material because they are directly involved and active in the learning process. The scientific approach will facilitate the students to understand the concept. The concept of the learning process by scientific approach will be more memorable, stored as long-term, and a good basic for the students. Understanding the concept has a very important role because the students may have progress to higher cognitive levels if they have a good understanding to the concept. Widyastuti \& Pujiastuti (2014, p. 184) suggests, "Conceptual understanding is the students' ability in master a concept/material that is indicated in the cognitive domain. By understanding a concept, students may know, explain, describe, compare, differentiate, classify, give a thing of which is an example and which is not an example, summarize and re-state of an object on their explanation considering to every processes".

If the understanding can be mastered properly, then the students will able to connect or associate a concept with one other concept. In addition, the material in science learning is a continuous material which one concept may use as a support for another concept, then, one concept may use to solve the problems from simple to complex.

Phang \& Tahir (2012, p. 307) states, "scientific skills such as making hypotheses, making inferences and stating variables are fundamental skills in scientific investigation". The scientific process skill involves making hypotheses to make conclusions. The scientific approach guides students to become scientists due to the steps in scientific approach follow the way of scientist to find out the theory. The scientific approach involves students in a complex problem-solving activitiy through discussion, creative thinking, conducting research activities, and building knowledge concepts. Learning using scientific approach provides the widest opportunity to students to do the contextual learning, and the learning becomes more meaningful (meaningful learning).

Various studies on the relationship between the implementation of a scientific approach and critical thinking skills showed the conclusion that the scientific approach has an effect on students' critical thinking. Based on the description, it is necessary to apply the scientific approach in science learning process at SD first cluster of Palakka District, Bone regency. Science learning by implent a scientific approach in class V SD first cluster of District Palakka will make the students easier to understand the subject matterial provided by the teacher. Scientific approach in learning may improve the students' ability to understand the concept and critical thinking skills, and then the learning objectives are able to achieve.

The research was conducted in class $\mathrm{V}$ SD first cluster of District Palakka, Bone regency, because in the learning process use a conventional learning by lecturing method, 
meanwhile the concept comprehension and critical thinking of the students has not facilitated optimally.

The particular research aimed to determine: (1) the effect of scientific approach through understanding concept in science, (2) the effect of scientific approach through critical thinking in science, and (3) the effect of scientific approach through understanding concept and critical thinking in science.

The research significances include of theoretical and practical significances. Theoretical significances may add as the reference in further research especially for the subjects of Natural Sciences (IPA) for class V in elementary school. The practical significances, for students, the particular research may improve the students' understanding of concept and critical thinking skills of science. For teachers, the particular research may use as materials to develop the methods or approaches in classroom learning that aim to improve the quality of learning. For researchers, the particular research is expected to provide practical experience and insight in the development and improvement of science learning in elementary school.

\section{Method}

The research type was quasi experiment. Time of the research was conducted in the second semester of academic year 2016/2017. The research conducted in first cluster of Palakka district, Bone regency.

The population of the particular research was the fifth grade school elementary students in the first cluster of Palakka district Bone regency amounted of 6 schools. Technique of collecting sample was cluster random sampling to determine 3 classes, which were; SD Negeri 28 Usa (22 students) and SD Inpres 5/81 Passippo (26 Students) as experiment class 1 and experiment class 2, meanwhile SD Negeri $30 \mathrm{Mico}$ (23 students) as a control class.

The research design was pretest posttest control group design (Isaac \& Michael, 1995, p. 66). In the design, there were three randomly selected groups, and the groups were assumed as had the same characteristics (homogeneous). Two classes were had treatment (experiment), and one class was as control class. The three classes were given pretest to know the students' initial ability, then they were given treatment for the experimental group, and the last, they were given posttest to know the students' final ability after treatment.
Data collection techniques in the research were tests in the form of written test to determine the understanding of the concept and students' critical thinking. The tests were conducted at the beginning of learning (pretest), and after the students followed the learning process (posttest). The form of test was essay. If the test score result after treatmeant showed that the experiment class is better than control class, and then, there is an influence from the treatment.

The steps of the research were: (1) preparation; in this steps, the teacher and students determined the learning objectives, the object in the learning, the way of learning, and other technical preparation, (2) implementation; in this steps, the teacher and students conducted the learning process according to teaching plan (3) further action, in this last step, teacher and students discussed the results of learning where each group were asked to report the learning outcomes and discuss together.

Data analysis techniques in the particular research used descriptive statistics and inferential statistics. Descriptive analysis was used to describe the obtained data to support the discussion of the research. Statistical techniques used to describe the pretest and posttest data of the experimental group and the control group including mean, median, mode, standard deviation, variance, minimum score, and maximum score. Inferential analysis was used to test the hypotheses.

The research consisted of independent variable that is scientific approach $(\mathrm{X})$, and dependent variable is concept comprehension (Y1) and critical thinking (Y2). Instrument validations in the research were content and construct validation. Content and construct validation was obtained by making instrument grid, and then continued to validate instrument with expert judgment. After validation test, it continued to instrument test, and then analyzed using statistical test of person correlation. The instrument of reliability test conducted by observed the coefficient score of Alpha Cronbach.

In the hypothesis test, there were two data analysis techniques which were independent $t$ test and Multivariate Analysis of Variance (MANOVA). In the hypothesis test began with the average difference test using independent $t$ test, and the test aimed to know the effect of scientific approach through understanding concept and critical thinking in science separately. The next hypothesis test with MANOVA aimed to know both the effect of scientific approach 
through understanding concept and critical thinking in science.

Before the inferential statistical test, the data must meet the prerequisite tests which were the normality test and homogeneity test. Normality test was conducted by kolmogrovsminorv, and the test aimed to know the data was normally distributed or not. Meanwhile, the homogeneity test aimed to know the data were from a homogeneous population or not by using levene's test. Data was normal distribution and homogeneous if the significance score was $>$ 0.05 . The hypothesis test used SPSS 23 for windows.

\section{Results and Discussions}

Descriptive Analysis

Descriptive analysis in the particular research aimed to describe the pretest and posttest data of the experimental class and control class using statistical techniques which are mean, median, mode, standard deviation, variance, maximum score, and minimum score. The result of descriptive analysis of pretest data of students' concept understanding on science of experimental class 1 and 2, and control class, is presented in Figure 1.

The result of descriptive analysis of posttest data of students' concept understanding on science of experimental class 1 and 2, and control class, is presented in Figure 2. The result of descriptive analysis of pretest data of students' critical thinking on science of experimental class 1 and 2, and control class, is presented in Figure 3. The result of descriptive analysis of posttest data of students' critical thinking on science of experimental class 1 and 2, and control class, is presented in Figure 4. In sum, the scientific approach on the experimental group has more positive effect on the students' concept understanding on science learning of class V SD.

\section{Inferential Analysis}

The prerequisite test was conducted before the hypothesis test. The prerequisite tests were normality and homogeneity test to each class. Normality test was conducted by kolmogrov-sminorv, and the test aimed to know the data was normally distributed or not. Meanwhile, the homogeneity test aimed to know the data were from a homogeneous population or not of experimental and control class. Table 5 is the score of the normality test analysis.

Based on Table 5, the results of normality test kolmogrov-smirnov of concept understanding and critical thinking in the experimental group 1, experimental group 2, and the control group have significance score higher than 0.05 , which means the data are normally distributed. Homogeneity test is presented in Table 6. Based on Table 6, the homogenity test results show that the levene statistic for concept understanding and critical thinking have significance score higher than 0.05 , which means the data are homogeneous.

After the prerequisite tests that are normality and homogeneity, then conducted hypothesis test. The test result is presented in Table 7. Based on Table 7, the results of the Independent Sample t-test for concept understanding and critical thinking show score less than 0.05 , it may conclude; (1) the scientific approach has more positive and significant effect to concept comprehension, and (2) scientific approach gives more positive and significant effect to students' critical thinking on science learning of class V SD. Manova test is used to test the further hypothesis and presented in Table 8.

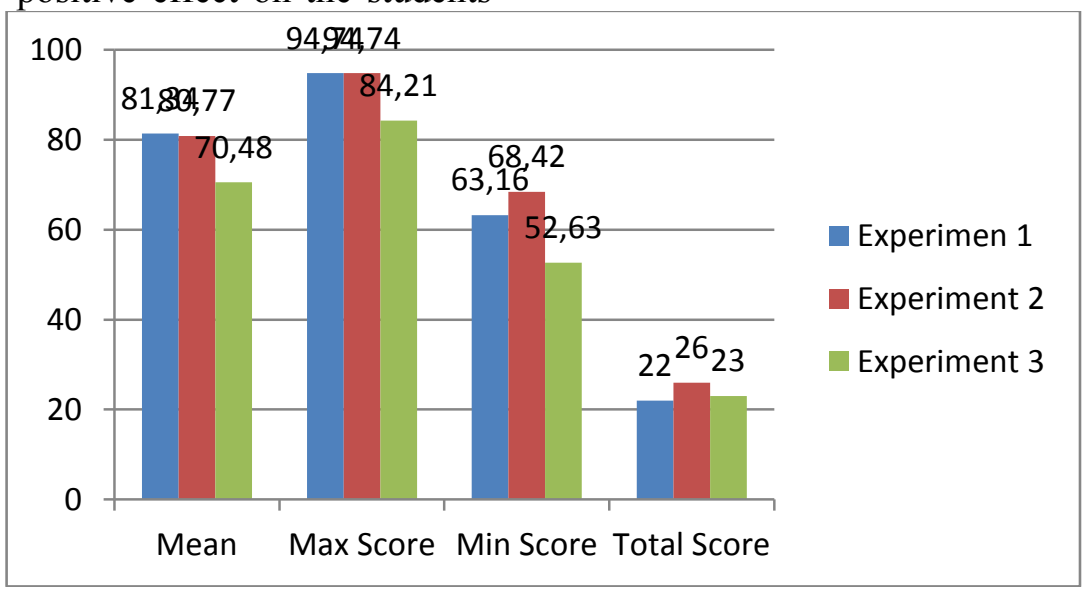

Figure 1. Pretest score of concept understanding 
Jurnal Prima Edukasia, 6 (1), January 2018 -26

S. Syarifuddin

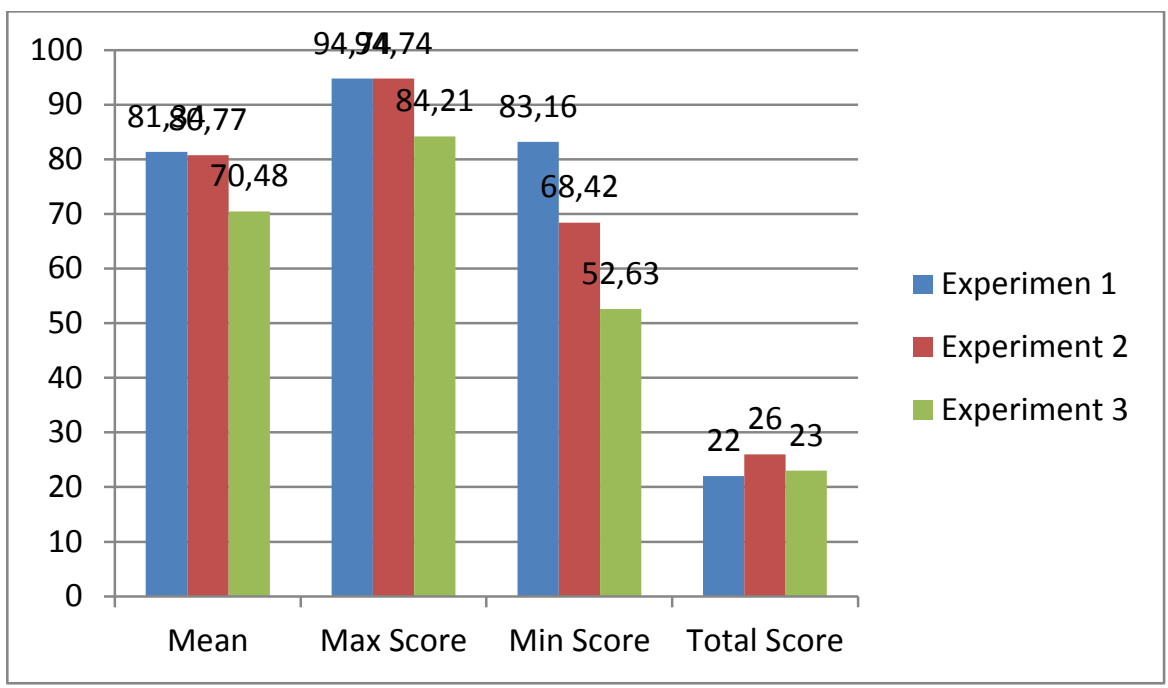

Figure 2. Posttest score of concept understanding

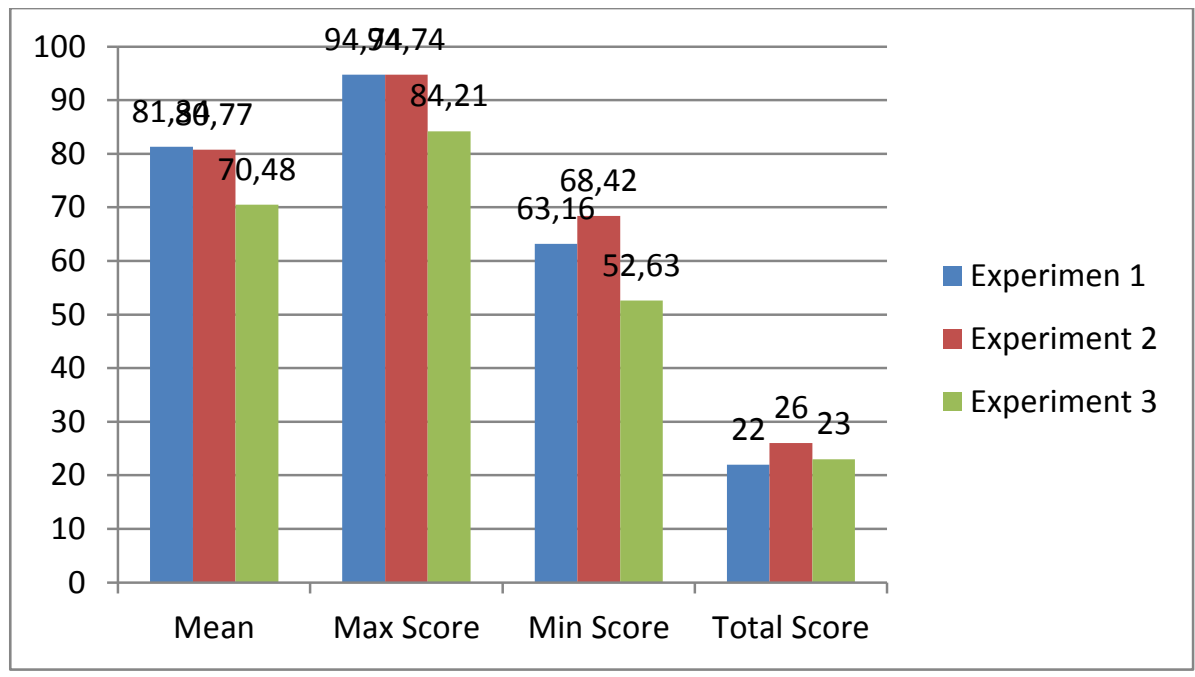

Figure 3. Pretest score of critical thinking

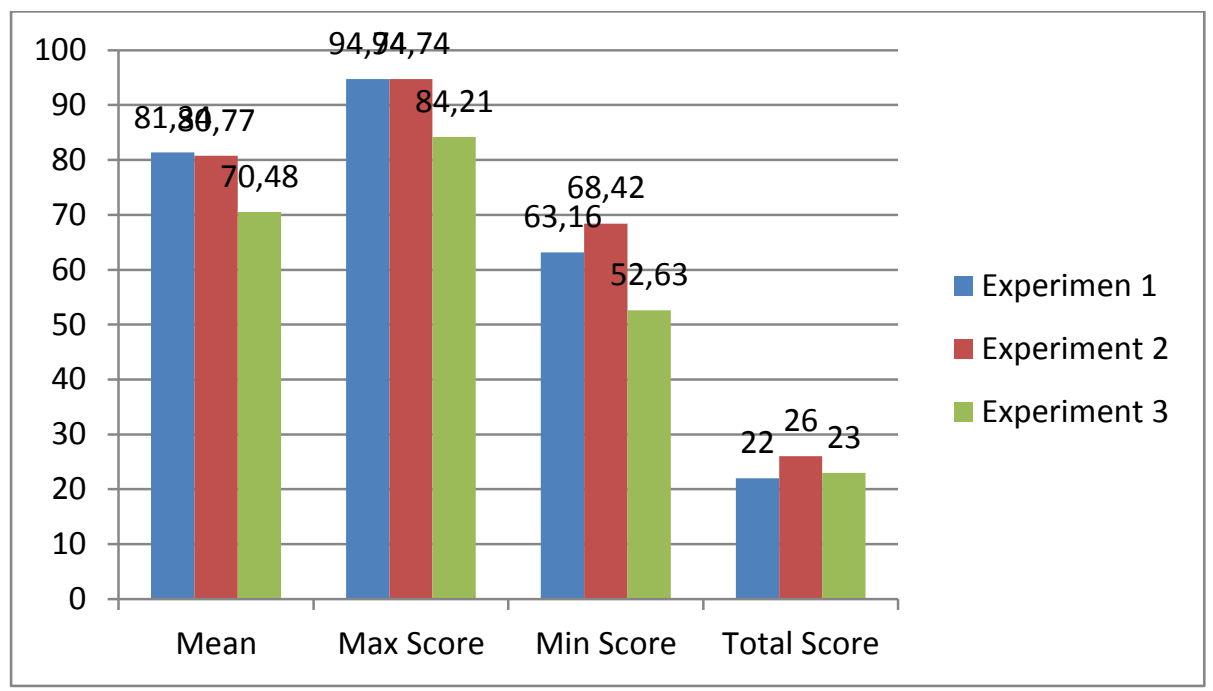

Figure 4. Posttest score of critical thinking 
Jurnal Prima Edukasia, 6 (1), January 2018 -27

S. Syarifuddin

Table 5. Kolmogrov-Smirnov Normality Test Results

\begin{tabular}{cccc}
\hline Data & Experiment Class 1 & Experiment Class 2 & Control Class \\
\hline Pretest of concept understanding & 0,103 & 0,124 & 0,126 \\
Posttest of concept understanding & 0,102 & 0,124 & 0,102 \\
Pretest of critical thinking & 0,147 & 0,133 & 0,134 \\
Posttest of critical thinking & 0,200 & 0,185 & 0,079 \\
\hline
\end{tabular}

Table 6. Homogenity Test Results

\begin{tabular}{ccc}
\hline Data & Levene Statistic & Sig. \\
\hline Pretest of concept understanding & 0,595 & 0,554 \\
Posttest of concept understanding & 0,034 & 0,967 \\
Pretest of critical thinking & 1,365 & 0,262 \\
Posttest of critical thinking & 0,271 & 0,763 \\
\hline
\end{tabular}

Table 7. Test Results of Independent Sample t-test

\begin{tabular}{cccc}
\hline Data & $\boldsymbol{T}$ & Sig(2-tailed) & Description \\
\hline Concept Understanding & 3.081 & 0.003 & There is a difference \\
Critical Thinking & 4,632 & 0.000 & There is a difference \\
\hline
\end{tabular}

Table 8. Manova Test Results

\begin{tabular}{cccc}
\hline Aspect of Assessment & Data & Sig & Description \\
\hline Both of concept understanding and critical thinking & Posttest & 0.000 & There is a difference \\
\hline
\end{tabular}

Based on Table 8, the manova test result for both concept understanding and critical thinking show the score less than 0.05 , it means the score proves that there is mean differences of concept understanding and critical thinking in the experimental group and the control group. And it may conclude that the scientific approach has a positive and significant effect to students' concept understanding and critical thinking on science learning in class V SD.

\section{Discussion}

Based on the result of data analysis and hypothesis test that conducted on the research data aiming to know the effect of the use of scientific approach through students' concept understanding and critical thinking on the science learning of class V SD first cluster of Palakka, Bone, then the result is explained in some parts;

\section{The effect of using Scientific Approach through Students' Concept Understanding on Science Learning.}

The research was conducted at three schools of first Cluster Palakka district, Bone regency, which are class 5 of SD Negeri 28 Usa as experimental group I, Class 5 of SD Inpres 5/81 Passippo as experimental group II, and class V of SD Negeri 30 Mico as control group. The particular research is expected to provide an alternative in science learning especially in force materials and simple plane.
The data of students' concept understanding consists of initial capability data and students' final ability. The initial capability data is obtained from the test result before the learning process (pretest), meanwhile the students' final ability data is obtained from the test result after the learning process (postest). Based on the calculation of the test score, the average pretest score of the control class is 56.52 , the experimental class I is 55.00, and the experimental class II is 60.77. Meanwhile, the mean of postest in control class is 70.43 , the experimental class 1 is 79.55 , and the experimental class 2 is 80.77 . The effect of scientific approach through students' concept understanding may see from the significance score of 0.003 . And then, in sum, the scientific approach has significant positive effect on students' concept understanding.

The concept understanding is an important aspect that must master by students due to it is the basic for students to solve the problems. This is supported by Krathwohl (2002, p. 215), states "Understand is determining the meaning of instructional messages, including oral, written, and graphic communication. Interpreting, Exemplifying, Classifying, Summarizing, Inferring, Comparing, Explaining", that understanding is a part of the cognitive process dimension in Bloom's Taxonomy, if the student is able to understand an object or concept, then he/she is able to construct the meaning of instructional 
messages, including oral, written, and graphic communication.

Nichols \& Stephens (2013, p. 1) in the scientific approach learning is used to test hypotheses, answer questions, and formulate the theories. Thus, the process of understanding not only stops at the student able to solve the problem by answer the question, but also extent to draw the students able to formulate the problem. The learning process by apply the scientific approach may train the students to have critical thinking analytically in making decisions, then the students not only listen and memorize the learning materials.

Supported by Zaim (2017, p. 33) states "Scientific approach has the characteristics of "doing science" that allows teachers to improve the process of learning by breaking the process down into steps that contain detailed instruction for conducting student learning". In learning process using scientific approach, there are some steps that guide the students to understand the material. The steps guide the students to learn while do the experiments, the learning process seem able to make students better understand the concept of the learning. Students learn with their own experience without only memorize the concept.

\section{The Effect of Using Scientific Approach through Students' Critical Thinking on Science Learning.}

From the analysis results on table 16, the Indicators conclude in highest score of $100 \%$ in the experimental class due to the learning process by using a scientific approach train the students to draw conclusions based on experiments. And other reasons are because the continuous practice of each meeting through the LKS (Students' worksheet) that guides the students to draw a conclusion. Meanwhile, the basic skills building indicators is in lowest score of $63.6 \%$ in the experimental class. Sanjaya (2015, p. 202) states the knowledge is gained through direct experience and indirect experience. The more directly the object is learned, the more concrete the knowledge is gained. And the more indirect the knowledge is gained; the student's knowledge is more abstract. The scientific approach is an approach that facilitates students to learn directly with real objects, in other words, through scientific approach, there is increasing on students' knowledge including concept understanding and students' critical thinking ability.
Based on the test score calculation, the average score of pretest on control class is 57.66, experimental class 1 is 55.02, and experimental class II is 52.83. Meanwhile, the average score of posttest on control class is 70.48, experiment class $\mathrm{I}$ is 81.34, and experiment class II is 80.77. The effect of scientific approach through students' critical thinking may see from the significance score of 0.000 . And then, in sum, the scientific approach has significant positive effect on students' critical thinking.

Lastriningsih (2017, p. 69) states the aspects of critical thinking skills include of problems identification, analyzing, and concluding. Problems identification means, students are able to formulate the main issues. Analyzing means, students are able to relate the problem with relevant information to solve the problem. And, concluding means, students are able to draw conclusion based on analysis result.

Critical thinking is needed by every individual to address the problems of life. Kartimi et al. (2012, p. 21), Critical thinking allows the students to discover the truth of each events and information on daily. Thus, the students' critical thinking skills are the students' way of thinking to analyze the argument and generate the insight into each meaning, interpretation, and develop a cohesive and logical reason pattern. In critical thinking, a person may able to organize, adjust, change, or rethink his/her mind in order he/she can act more appropriately. A person who has critical thinking is a skilled person of reason. $\mathrm{He} / \mathrm{she}$ has the ability to use a reason in a context where the reason is used as the rationale. A person who has Critical thinking will decide and think rationally through multiple views of different contexts. They will prepare to make reasons and decisions about what is seen, heard, or thought.

The learning process by memorizing is not enough facilitate the students to develop their thinking skills. Koksal \& Berberoglu (2014, p. 67) states "In science education, teaching through inquiry is one of the basic requirements to develop scientific thinking skills in students". To develop their thinking skills, students must conduct an inquiry to draw the right conclusions. The inquiry means an inquiry based on the steps of the scientific process.

McLelland (2014, p. 2) argues that the scientific approach is important for students because the approach is a form of critical thinking whose the steps consist of observation, 
questioning, experimenting, hypothesizing, evaluating and analyzing, and communicating. The learning encourages the students to experiment with the material to collect the information. Glazunov (2012, p. 10) states the scientific approach is the learning with collecting data through observation, experimentation, formulation, and hypothesis testing.

Learning using scientific approach may improve the students' critical thinking ability because students are trained to observe, question, experiment, reason, and communicate through the stages of scientific process. Learning through scientific approach is a learning process which is designed in order the students actively construct the concepts, laws or principles through observing stages (to identify or find problems), formulating the problems, proposing or formulating the hypotheses, collecting data with various techniques, analyzing the data, drawing conclusions and communicating concepts, and laws or principles. Students become the main subjects in the scientific approach, students may active in learning, and provide opportunities for students to build concepts in knowledge independently, make usual the students in formulating, dealing with, and solving the problems. Thus, students may improve their understanding of a certain material, then they are able to have critical thinking skills. In short, the scientific approach is appropriate to improve the students' critical thinking ability.

The Effect of Using Scientific Approach through Students' Concept Understanding and Critical Thinking on Science Learning.

The effect of independent variable to dependent variable in manova test is seen by the significance score, if the significance score < 0,05 then the independent variable may conclude as have an effect to dependent variable. The effect of independent variable to two dependent variables in the manova test is seen by the significance score of Hotteling's Trace on the output Multivariate Test. The significance score shows that the scientific approach has an effect to concept understanding and critical thinking with a significance score of 0.000 .

The scientific approach is a studentcentered approach. Direct involvement of students in the learning process will increase the students' attention during the learning process, and it may have an effect to improve the student learning outcomes. It appropriate to Mantu \&
Katircioğlu (2013, p. 627) states, "The students with the skills acquired by the scientific method, while the easier to understand, and can they ever love the science courses". The students will easily understand when learning by using a scientific approach, and students will more love the learning process. Learning while playing make students more pleasant, and students will be more active than learning by memorizing method.

The scientific approach provides students an opportunity to discover their own concepts through a pleasant experiment. Through a pleasant experiment, students may have their own learning experience, and the students will gain meaningful knowledge. In addition, by a pleasant learning, it will attract the students' motivation in teaching and learning process, and the learning objectives will achieve well.

The critical thinking ability is very useful to students to solve the problems. Chukwuyenum (2013, p. 18) states "Critical Thinking has been one of the tools used in our daily life's to solve some problems because it involves logical reasoning, interpreting, analysing and evaluating information to enable one take reliable and valid decisions". Making the reliable and valid decision by using logical reasoning, interpreting, analyzing, and evaluating information makes the critical thinking as a tool that enable the students in solving the problems. Supported by Cekin (2015, p. 159), critical thinking ability involves an advanced learning than only memorize the facts. They may make it possible to analyze the topics, evaluate the solutions, and synthesize their own opinions. All these things are very appropriate to the implementation of a scientific approach. By these skills, the conclusions are drawn in more reliable and valid.

\section{Conclusions}

Based on the research results and discussion, it may conclude that: (1) There is a significant positive effect of scientific approach through students' concept understanding in science class $\mathrm{V}$ elementary school with the sign score of 0.003 , (2) There is a significant positive effect of scientific approach through students' critical thinking in science class $\mathrm{V}$ elementary school with the sign score of $0.000,(3)$ there is a significant positive effect of scientific approach through students' concept understanding and critical thinking in science class $\mathrm{V}$ elementary school with the sign score of 0.000 . 
In choose a learning approach, the teacher should provide an approach that enable the students to develop the concept understanding by giving students an opportunity to find out and train the students' thinking skills, moreover the teachers also consider the approaches relate to their daily. A teacher may apply a scientific approach in learning where provide students an opportunity to understand, feel, and know the material directly.

\section{References}

Abante, M. E. R., Almendral, B. C., Manansala, J. E., \& Mañibo, J. (2014). Learning styles and factors affecting the learning of general engineering students. International Journal of Academic Research in Progressive Education and Development, 3(1), 2226-6348. https://doi.org/10.6007/IJARPED/v3i $1 / 500$

Cekin, A. (2015). The investigation of critical thinking dispositions of religious culture and ethics teacher candidates. Journal of Education and Learning (EduLearn), 9(2), 158.

https://doi.org/10.11591/edulearn.v9i2.171 8

Chukwuyenum, A. N. (2013). Impact of critical thinking on performance in mathematics among senior secondary school students in Lagos State. IOSR Journal of Research \& Method in Education, 3(5), 18-25. Retrieved from www.iosrjournals.org

Dewi, A. E. A., \& Mukminan, M. (2016). Implementasi pendekatan saintifik dalam pembelajaran IPS di middle grade SD Tumbuh 3 Kota Yogyakarta. Jurnal Prima Edukasia, 4(1), 20-31. https://doi.org/10.21831/jpe.v4i1.7691

Glazunov, N. M. (2012). Foundations of scientific research (Foundations of Research Activities). Retrieved from http://arxiv.org/abs/1212.1651

Gömleksiz, M. N. (2012). Elementary school students' perceptions of the new science and technology curriculum by gender. Educational Technology \& Society, 15(1), 116-126. Retrieved from http://www.ifets.info/journals/15_1/11.pdf

Isaac, S., \& Michael, W. B. (1995). Handbook in research and evaluation: A collection of principles, methods, and strategies useful in the planning, design, and evaluation of studies in education and the behavioral sciences. Cambridge: EdITS.

Kartimi, K., Liliasari, L., \& Permanasari, A. (2012). Pengembangan alat ukur berpikir kritis pada konsep senyawa hidrokarbon untuk siswa SMA di Kabupaten Kuningan. Jurnal Pendidikan MIPA, 13(1), 18-25. Retrieved from http://jurnal.fkip.unila.ac.id/index.php/JPM /article/view/397/154

Koksal, E. A., \& Berberoglu, G. (2014). The effect of guided-inquiry instruction on 6th grade Turkish students' achievement, science process skills, and attitudes toward science. International Journal of Science Education, 36(1), 66-78. https://doi.org/10.1080/09500693.2012.72 1942

Krathwohl, D. R. (2002). A revision of Bloom's taxonomy: An overview. Theory Into Practice, 41(4), 212-218. https://doi.org/10.1207/s15430421tip4104_ 2

Lastriningsih, L. (2017). Peningkatan berpikir kritis dan prestasi belajar melalui metode inquiry pada siswa kelas IV SD. Jurnal Prima Edukasia, 5(1), 68-78. https://doi.org/10.21831/jpe.v5i1.7714

Mantu, A. K., \& Katircioğlu, H. (2013). Application of empathy influence on the image of scientist and scientific methods within the scope of biology lesson. Procedia - Social and Behavioral Sciences, 89 , 627-632. https://doi.org/10.1016/J.SBSPRO.2013.08 .906

McLelland, C. V. (2014). The nature of science and the saintific method. Columbus: The Geological Society of America. Retrieved from https://www.geosociety.org/documents/gsa /geoteachers/NatureScience.pdf

Nichols, A. J., \& Stephens, A. (2013). The scientific method and the creative process: Implications for the K-6 classroom. Journal for Learning through the Arts, 9(1), 1-12. Retrieved from http://escholarship.org/uc/item/0z72t75q

Phang, F. A., \& Tahir, A. (2012). Scientific skills among pre-service science teachers at Universiti Teknologi Malaysia. Procedia -Social and Behavioral Sciences, 
Jurnal Prima Edukasia, 6 (1), January 2018 -31

S. Syarifuddin

56 ,

307-313. https://doi.org/10.1016/j.sbspro.2012.09.65 9

Presiden Republik Indonesia. Undang-Undang Republik Indonesia nomor 20 tahun 2003 tentang sistem pendidikan nasional, Pub. L. No. 20, Undang-Undang Republik Indonesia 26 (2003). Indonesia. Retrieved from

http://www.dpr.go.id/dokjdih/document/uu 1591.pdf

Sanjaya, W. (2015). Perencanaan dan desain sistem pembelajaran. Jakarta: Kencana Prenadamedia Group.

Sumaryati, E., \& Sumarmo, U. (2013). Pendekatan induktif-deduktif disertai strategi think-pair-square-share untuk meningkatkan kemampuan pemahaman dan berpikir kritis serta disposisi matematis siswa SMA. Infinity Journal, 2(1), https://doi.org/10.22460/infinity.v2i1.22

Widiawati, N. P., Pudjawan, K., \& Margunayasa, I. G. (2015). Analisis pemahaman konsep dalam pembelajaran ipa pada siswa kelas IV SD di gugus II Kecamatan Banjar. MIMBAR PGSD Undiksha, 3(1). Retrieved from https://ejournal.undiksha.ac.id/index.php/JJ PGSD/article/view/5847

Widyastuti, N. S., \& Pujiastuti, P. (2014). Pengaruh pendidikan matematika realistik indonesia (PMRI) terhadap pemahaman konsep dan berpikir logis siswa. Jurnal Prima Edukasia, 2(2), 183. https://doi.org/10.21831/jpe.v2i2.2718

Zaim, M. (2017). Implementing scientific approach to teach English at senior high school in Indonesia. Asian Social Science, 13(2), 33-40. https://doi.org/10.5539/ass.v13n2p33 